\title{
Chemical characterization and bioactive compounds of an unconventional vegetable - Erechtites valerianifolia (Wolf) DC.
}

\author{
Tibério Fontenele BARREIRA ${ }^{1}$, Galdino Xavier de PAULA FILHO ${ }^{2 *}$ (D), Soraia Silva PINHEIRO 3 , \\ Leandro de Morais CARDOSO ${ }^{4}$, Ricardo Henrique Silva SANTOS ${ }^{5}$, Helena Maria PINHEIRO-SANT'ANA ${ }^{3}$
}

\begin{abstract}
Erechtites valerianifolia (Wolf) DC is an unconventional vegetable found in the Brazilian Atlantic Forest. Is consumed in high proportions by the population living in this biome. The objective of this study was to investigate the general chemical composition, occurrence and content of carotenoids, vitamins (C and $\mathrm{E}$ ) and minerals in this vegetable. By the micro-Kjeldhal method it was determined proteins. It was determined total dietary fiber (TDF) by non-enzymatic gravimetric method. Carotenoids and vitamins were determined by high performance liquid chromatography (HPLC). In inductively coupled plasma-atomic

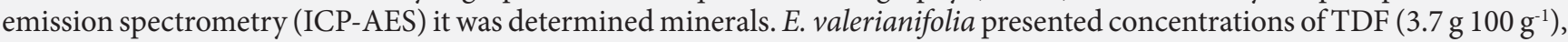

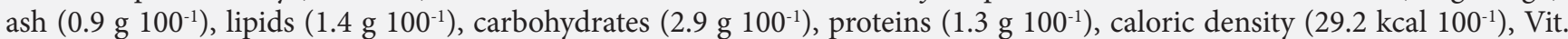

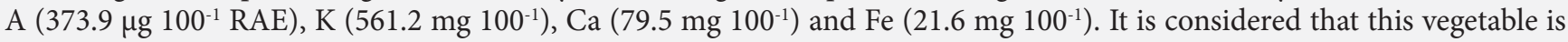
source of $\mathrm{Ca}$, good source of fiber and $\mathrm{K}$, and an excellent source of pro-vitamin $\mathrm{A}, \mathrm{Mn}, \mathrm{Se}, \mathrm{Fe}, \mathrm{Mo}$ and $\mathrm{Cu}$, which may reduce food and nutritional insecurity in the population, mainly in the region where this species is found.
\end{abstract}

Keywords: Erechtites valerianifolia; Brazilian Atlantic forest; capiçova; food alternative resources.

Pratical Application: Analysis of the nutritional composition of unconventional vegetable.

\section{Introduction}

Native species may represent alternatives to human nutrition and insertion of new food sources in markets, since Brazilians eat less than half of the daily nutrient recommendations, and this consumption is lower among low-income families (Pereira et al., 2014). It is stressed that the consumption of these species may represent a new dietary option, mainly related to healthy eating (Friel et al., 2014).

Although many native foods are part of the Brazilian diet, there is still limited information on their nutritional composition (Paula Filho et al., 2015a). However, the inclusion of information on nutritional composition becomes important to evaluate the supply of these food sources and to verify the possibility of nutritional adequacy of these foods in the diet (Paula Filho et al., 2015b).

Erechtites valerianifolia (Wolf) DC. is an unconventional vegetable that belongs to the family Asteraceae and is widely distributed all the Brazilian Atlantic Forest biome. This vegetable is used as a food resource, specially by families inhabiting the rural area of this region, being commercialized in urban fairs as well (Barreira et al., 2015). Although its importance and use in the diets of many families is observed, up to the present time the nutritional composition of this vegetable is still little studied.
Among works found on this species, stands out Wahab et al. (2015) who evaluated the nutritional value and bioactive components in samples of E. valerianifolia consumed by indigenous populations in Malaysia, these authors found high concentrations of $\beta$-carotene, carbohydrates and vitamin $\mathrm{C}$ in this species. Rosas-Romero \& Saavedra (2005) observed that samples of E. valerianifolia collected in the District of Chapare, in Bolivia, presented antioxidant activity highly promising. As well, there is no record in the academic literature of some possible toxicity effect that the species may present, in this case, when there is, is eliminated by means of the preparation forms carried out by the families that consume this species.

Considering the above, the present study investigated the centesimal analysis, content of carotenoids, vitamins (C and E) and minerals in samples of E. valerianifolia collected in natural environments of the Brazilian Atlantic Forest.

\section{Material and methods}

\subsection{Obtaining of the samples}

Fertile samples of E. valerianifolia were obtained in November of 2012 , in the region of Viçosa $\left(20^{\circ} 45^{\prime} 14^{\prime \prime} \mathrm{S}\right.$ and $\left.42^{\circ} 52^{\prime} 44^{\prime \prime} \mathrm{W}\right)$, and identified by experts from the herbarium of the Federal

${ }^{1}$ Departamento de Fitotecnia, Universidade Estadual do Norte Fluminense Darcy Ribeiro - UENF, Campos dos Goytacazes, RJ, Brasil

${ }^{2}$ Departamento de Educação, Universidade Federal do Amapá - UNIFAP, Mazagão, AP, Brasil

${ }^{3}$ Departamento de Nutrição e Saúde, Universidade Federal de Viçosa - UFV, Viçosa, MG, Brasil

${ }^{4}$ Departamento de Nutrição, Universidade Federal de Juiz de Fora - UFJF, Governador Valadares, MG, Brasil

${ }^{5}$ Departamento de Fitotecnia, Universidade Federal de Viçosa - UFV, Viçosa, MG, Brasil

*Corresponding author: galdinoxpf@gmail.com 
University of Viçosa, Minas Gerais, Brazil (IAC: 39256). Posteriorly, fresh samples were collected for chemical analysis. The leaves of these plants constituted the samples obtained in five distinct locations, characterizing the replicates. Being obtained $0.5 \mathrm{~kg}$ of leaf, of at least ten different plants, to compose each replicate.

After collection, the samples were protected from light, taken to the laboratory, sanitized and subsequently wiped with paper towel. Then, they were crushed in a household food grinder (Philips $^{\circledR}$, RI 7625, Brazil), stored in polyethylene packaging covered in foil and packed in a freezer $\left(-18 \pm 1{ }^{\circ} \mathrm{C}\right)$. Analyzes of vitamin $C$ and carotenoids were performed within $12 \mathrm{~h}$ after collection, while vitamin $\mathrm{E}$ analyzes were performed within $72 \mathrm{~h}$ after collection.

\subsection{General chemical composition}

The water content and the concentration of ash, total dietary fiber, protein and lipid were analyzed in three replicates, using the methods of the Association of Official Analytical Chemists (2010). The water content was determined in oven at $105 \pm 1^{\circ} \mathrm{C}$ for $24 \mathrm{~h}$, and then the samples were weighed until reaching constant weight. Ashes in a muffle oven (QUIMIS) at $550^{\circ} \mathrm{C}$ during $6 \mathrm{~h}$. Concentration of proteins was quantified in micro-Kjeldhal and then the nitrogen $(\mathrm{N})$ content was multiplied by 6.25 . The total dietary fiber concentration it was determined by non-enzymatic gravimetry. Carbohydrates were quantified by equation: [100 - \% water - $\%$ lipids - $\%$ proteins - $\%$ TDF - $\%$ ash]. Caloric density was determined according to the method proposed by Frary \& Johnson (2005), using the conversion factors of $4 \mathrm{Kcal} \mathrm{g}^{-1}$ of carbohydrate and protein, and $9 \mathrm{Kcal} \mathrm{g}^{-1}$ of lipids.

\subsection{Equipment and methods of analysis in carotenoids and vitamins}

Analyses of carotenoid and vitamin $\mathrm{C}$ were performed in a CLAE system (Shimadzu, SCL 10AT VP, Japan) containing a high-pressure pump (LC 10AT VP), auto-injector SIL-10AF and (diode array detector) (DAD) (SPD-M10A). In vitamin E analysis, was used aCLAE system (Shimadzu, SCL 10AD VP, Japan) composed by fluorescence detector (RF-10A XL), high-pressure pump (LC 10AD VP) and automatic injector SIL-10AF.

$\alpha$-carotene, $\beta$-carotene, $\beta$-cryptoxanthin and lycopene were extracted in acetone and separated in petroleum ether (Rodriguez-Amaya et al., 1976). The chromatographic conditions for carotenoids analysis were used according to PinheiroSant'Ana et al. (1998): HPLC-DAD system, Phenomenex Gemini chromatography column RP-18, fitted with a Phenomenex ODS guard column and mobile phase with methanol: ethyl acetate: acetonitrile (70:20:10, v/v/v) and flow of $1.7 \mathrm{ml} \mathrm{min}^{-1}$. Run time of 12 minutes and chromatograms obtained at $450 \mathrm{~nm}$.

The vitamin A content was determined considering that 1 Retinol Activity Equivalent (RAE) is equivalent to $1 \mu \mathrm{g}$ of retinol; $12 \mu \mathrm{g}$ of $\beta$-carotene; $24 \mu \mathrm{g}$ of other carotenoids (Institute of Medicine, 2011).

The extraction of ascorbic acid (AA) occurred according to Campos et al. (2009), using buffer solution $\left(3 \% \mathrm{HPO}_{3}, 8 \%\right.$ acetic acid, $0.3 \mathrm{~N} \mathrm{H}_{2} \mathrm{SO}_{4}$ and $1 \mathrm{mM}$ EDTA). The DHA was converted in
AA using dithiothreitol as proposed by Pinheiro-Sant'Ana et al. (1998). The chromatographic conditions used in the analysis of AA were proposed by Campos et al. (2009), the HPLC system used was the same for carotenoids. Column Lichrospher 100 was used, equipped with a guard column (Phenomenex ODS); mobile phase elaborated with ultrapure water containing $1 \mathrm{mM}$ $\mathrm{NaH} 2 \mathrm{PO} 4$ and $1 \mathrm{mM}$ EDTA with $\mathrm{pH}$ adjusted in 3.0, with flow of $1.0 \mathrm{~mL}$ minute $^{-1}$. Run time of 8 minutes and chromatograms obtained at $245 \mathrm{~nm}$. The DHA concentration was determined by the equation: $D H A=A A$ concentration after conversion $A A$ concentration before conversion.

Eight components of vitamin E ( $\alpha-, \beta-, \gamma-, \delta$-tocopherol and $\alpha-, \beta-, \gamma-, \delta$-tocotrienol) were investigated. Extraction was performed using hexane: ethyl acetate $(85: 15, \mathrm{v} / \mathrm{v})$ solution (Pinheiro-Sant'Ana et al., 2011). The analysis was performed using the HPLC system, fluorescence detector LiChrosorb colum (Si100 Phenomenex) fitted with a guard column (Phenomenex Si100), mobile phase elaborated with hexane: isopropanol: glacial acetic acid (98.9: 0.6: $0.5, \mathrm{v} / \mathrm{v} / \mathrm{v})$, with flow of the mobile phase: $1.0 \mathrm{~mL} \mathrm{~min}{ }^{-1}$ andrun time of 22 minutes (Pinheiro-Sant'Ana et al., 2011).

\subsection{Determination of carotenoids and vitamins}

It was used vitamin $\mathrm{E}$ standards acquired from Calbiochem ${ }^{\circledR}$, EMD Biosciences, Inc. (USA) and L-ascorbic acid acquired from Sigma-Aldrich ${ }^{\circledast}$ (Germany). Standards of $\alpha$ - and $\beta$-carotene were prepared from extracts of Daucus carota L.; $\beta$-cryptoxanthin and lycopene were prepared from Carica papaya L. and Solanum lycopersicum L. extracts, respectively, all these in open-column chromatography (Rodriguez-Amaya, 1989).

The compounds were identifiedby comparing the retention times of the peaks observed in the standards and in the chromatograms of the analyzed samples. The identification of ascorbic acid and carotenoids occurred by comparison between the absorption spectra of the peaks in the samples and the standards. Vitamin E components were quantified by co-chromatography.

\subsection{Quantification of minerals}

Were extracted according to Gomes \& Oliveira (2011). The solution obtained during the extraction was used for mineral concentration reading in ICP-AES (Perkin Elmer).

In quantification, analytical curves were elaboradted using mineral standards acquired from Merck ${ }^{\circledR}$ (Brazil) and Vetec ${ }^{\circledR}$ (Brazil). Two standard multielement solutions (SPME) were elaboradted in 100-mL bottles. Standard multielement solutions 1 (SPME 1) was elaboradted for $\mathrm{Cr}, \mathrm{Se}, \mathrm{Mo}, \mathrm{Zn}, \mathrm{Cu}, \mathrm{Fe}$ and $\mathrm{Mn}$. SPME 2 was elaboradted for $\mathrm{Na}, \mathrm{P}, \mathrm{Mg}$, Ca and $\mathrm{K}$. When each SPME standard mixing was accomplished, the volume of the standards was filled with deionized water. During the construction of the standard curves, increasing portions of SPME 1 ( 0 to $2 \mathrm{~mL}$ ) with SPME 2 ( 0 to $20 \mathrm{~mL}$ ) were used, completed to $50 \mathrm{~mL}$ with distilled water for the construction of the curve with six points.

After the readings, the concentrations found, in the samples, in ppm $\left(\mathrm{mg} \mathrm{L}^{-1}\right)$ were converted to concentrations of minerals, according to the dilutions and their possible differences in relation to the blank. 


\subsection{Determmination of the nutritional potential of the E. valerianifolia}

The contribution as a source of nutrients was calculated according to the Recommended Dietary Allowance (RDA) for people aged 19 to 30 years according to the norms of the U.S. Institute of Medicine (2011). The quantities of E. valerianifolia were calculated based on the Food Guide for the Brazilian Population (Brasil, 2008), in which the caloric density equals a vegetable portion of $30 \mathrm{Kcal}$.

E. valerianifolia presented as a nutrients "source" when it presented the potential to supply 5 to $10 \%$ of RDA, "good source" when presented a potential between 10 and $20 \%$ of RDA and as "excellent source" with potential greater than $20 \%$ of these RDA (Philippi, 2008).

\subsection{Statistical design and data analysis}

In analysis of carotenoids and vitamins was used a randomized design with five replicates, and three replicates were used for general chemical characterization. The results were presented in mean, standard deviations and range of parameters. The linearity range of analytical standards were evaluated by the data obtained from the peak areas, used for the regression analysis and to calculate $\mathrm{R}^{2}$. Was used the SAS (Statistical Analysis System), version 9.2 (2008), to perform statistical analysis, whose system is licensed licensed for UFV (Federal University of Viçosa).

\section{Results and discussion}

E. valerianifolia was obtained from native plants, which develop spontaneously in wild environments and may present high genetic variability (El-Soda et al., 2014). In the present study there was no control of environmental variables (light, soil, temperature, water) in this species, which may alter nutrient content (Barrett et al., 2010).

It can be seen in Table 1 the high water content in the leaves of E. valerianifolia, which indicates low concentration of dry phytomass of some components (lipids, proteins, fibers, ashes and carbohydrates).

There are still few similar studies carried out with species of the genus Erechtites in the academic literature, making it difficult to compare the results of the present study. Therefore, it was observed that Wahab et al. (2015), in study accomplished on the nutritional composition of E. valerianifolia, found water

Table 1. General chemical composition and caloric value in leaves of E. valerianifolia.

\begin{tabular}{lc}
\hline \multicolumn{1}{c}{ Variables } & Mean \pm standard deviation \\
\hline Moisture $\left(\mathrm{g} 100 \mathrm{~g}^{-1}\right)$ & $91.1 \pm 2.2$ \\
$\mathrm{TDF}\left(\mathrm{g} 100^{-1}\right)$ & $3.7 \pm 0.03$ \\
Ash $\left(\mathrm{g} 100^{-1}\right)$ & $0.9 \pm 0.01$ \\
Lipids $\left(\mathrm{g} 100^{-1}\right)$ & $1.4 \pm 0.01$ \\
Carbohydrates $\left(\mathrm{g} 100^{-1}\right)$ & $2.9 \pm 0.6$ \\
Proteins $\left(\mathrm{g} 100^{-1}\right)$ & $1.3 \pm 0.07$ \\
Caloric value $\left({\left.\mathrm{kcal} 100^{-1}\right)}\right.$ & $29.2 \pm 3.3$ \\
\hline
\end{tabular}

Values obtained in fresh matter using mean of three replicates; TDF: total dietary fiber.

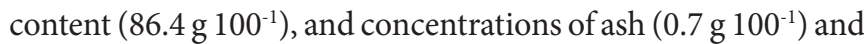

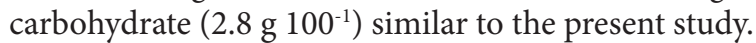

The high water concentration in the leaves of E. valerianifolia makes this species highly perishable and susceptible to microbial deterioration, which contributes to the reduction of shelf life when stored at room temperature (Corbo et al., 2009).

Analyzing the nutritional concentration in lettuce (Lactuca sativa L.), available in the Brazilian Food Composition Table (Universidade Estadual de Campinas, 2011), it is observed that some nutrients such as ash $\left(0.8 \mathrm{~g} 100^{-1}\right)$, carbohydrates

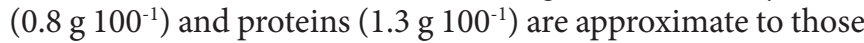
found in the present study. These species, although of different botanical genera, belong to the same botanical family, Asteraceae.

The caloric value of E. valerianifolia was higher than that of lettuce (14 Kcal $100 \mathrm{~g}^{-1}$ ), according to the Brazilian Food Composition Table (Universidade Estadual de Campinas, 2011). Even so, the caloric value presented by E. valerianifolia was considered low, so consumption of this vegetable by people who need to control weight constitutes an advantage.

In identification of carotenoids and vitamins the identified peaks allowed the quantification of the compounds, however, $\beta$-cryptoxanthin, lycopene, ascorbic acid and $\alpha-, \beta-, \gamma$ - and $\delta$-tocopherols and tocotrienols were not identified in samples of E. valerianifolia (Figure 1).
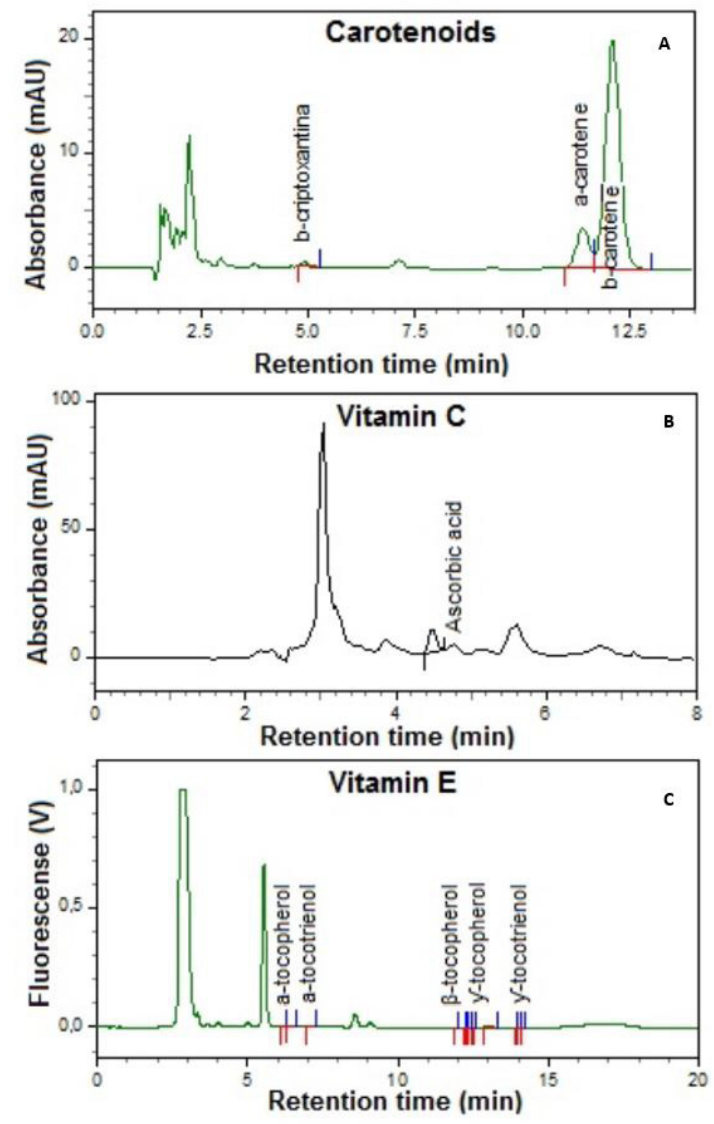

Figure 1. Chromatograms of carotenoid (A), vitamin C (B) and vitamin E (C) analyzes by HPLC in E. valerianifolia samples. 
The $\beta$-carotene is the one with has highest pro-vitamin activity among the carotenoids that can be transformed into vitamin $\mathrm{A}$ after human consumption, since, structurally, the $\beta$-carotene molecule corresponds to two molecules of retinol (vitamin A). This compound was majority in the leaves of E. valerianifolia, representing $89 \%$ of the total identified carotenoids (Table 2).

It was observed that the concentration of $\beta$-carotene found in the present study, is 2.4 times greater than the results found by Wahab et al. (2015) in E. valerianifolia $\left(1.8 \mathrm{mg} 100^{-1}\right)$. This difference may be due the two studies in question, were carried out with wild species, cultivated without control of environmental factors, which interfere in the concentration of nutrients, as emphasized by Barrett et al. (2010).

The retinol equivalent activity found in E. valerianifolia was higher than that of Garden, Smooth and Purple lettuces $\left(117,184\right.$ and $156 \mu \mathrm{g} 100 \mathrm{~g}^{-1}$, respectively) and Cichorium intybus intybus varieties $\left(283 \mu \mathrm{g} 100 \mathrm{~g}^{-1}\right.$ ) (Universidade Estadual de Campinas, 2011). These species belong to the botanical family of $E$. valerianifolia, despite being of different botanical genera.

Although in the present study, the presence of vitamin C in E. valerianifolia was not detected, it is emphasized that Wahab et al. (2015) they found concentration of $0.7 \mathrm{mg} 100^{-1}$ of this vitamin, in this same species. It was observed that this vitamin is present in some species of the same botanical family, such as lettuce, Icerbeg variety $\left(11 \mathrm{mg} 100^{-1}\right)$, Garden varitey (15 mg 100 ${ }^{-1}$ ) and Cichorium intybus intybus (1.7 mg 100 $\left.{ }^{-1}\right)$ (Universidade Estadual de Campinas, 2011).

Regarding vitamin E, no study on the evaluation of this vitamin in E. valerianifolia was found in the academic literature, nor even in species of the same botanical family.

The minerals with the highest occurrence in E. valerianifolia were mainly $\mathrm{K}$ and $\mathrm{Ca}$, but an expressive concentration of $\mathrm{Fe}$ and $\mathrm{Mg}$ was also found. The other minerals were found in reduced amounts, with Cr being found (Table 3).

Wahab et al. (2015) found concentrations of $\mathrm{K}\left(84 \mathrm{mg} \mathrm{100}^{-1}\right)$, Na

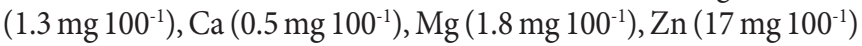

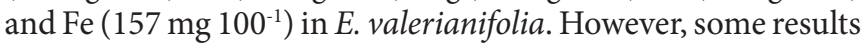
differ from those found here, which may be due to two factors. These authors used atomic absorption spectroscopy as analysis methodology, and analyzed fresh samples of E. valerianifolia, while the present study analyzed the concentration of minerals by ICP-AES in dry samples. Once the extraction efficiency of chemical compounds in plant sources may be more or less efficient according to the analysis methodology used, and also with the state in which the sample is being analyzed, whether fresh or dry (Ignat et al., 2011).

It shoud be stressed out that mineral concentration is not a conclusive indicator of the amount absorbed and used by the organism, since some such as $\mathrm{Fe}, \mathrm{Ca}, \mathrm{Cu}, \mathrm{Zn}$ and $\mathrm{Mg}$ may have low bioavailability due the formation of insoluble complexes, and consequently, antinutritional factors such phytate, oxalate and others (Gemede \& Ratta, 2014). Therefore, it is necessary to evaluate the antinutritional factors of this vegetable, since there are not studies with this purpose, yet.

By analyzing the contribution of E. valerianifolia to the daily recommendations of nutrients intake for adult at 19 to 30 years of age, it was observed that it can be considered source of $\mathrm{Ca}$; a good source of fibers and $\mathrm{K}$; and excellent source of pro-vitamin $\mathrm{A}$ and $\mathrm{Mn}, \mathrm{Se}, \mathrm{Fe}, \mathrm{Mo}$ and $\mathrm{Cu}$ (Table 4).

E. valerianifolia stood out as excellent source of Fe and exceeded the amount for RDA recommended for this nutrient, but not surpassed the tolerable consumption recommendations for adults in the age range of 19 to 30 years ( $\mathrm{UL}=45 \mathrm{mg} / \mathrm{day})$.

Table 2. Content of the carotenoids and vitamins in leaves of E. valerianifolia.

\begin{tabular}{lcc}
\hline \multicolumn{1}{c}{ Compounds } & Mean \pm standard deviation & $\%$ \\
\hline Total carotenoids $\left(\mathrm{mg} 100^{-1}\right)$ & $4.8 \pm 0.3$ & 100 \\
a-carotene $\left(\mathrm{mg} 100^{-1}\right)$ & $0.5 \pm 0.2$ & 11 \\
$\beta$-carotene $\left(\mathrm{mg} 100^{-1}\right)$ & $4.3 \pm 0.4$ & 89 \\
$\beta$-criptoxanthin $\left(\mathrm{mg} 100^{-1}\right)$ & nd & -- \\
Licopene $\left(m g ~ 100^{-1}\right)$ & nd & -- \\
Vitamin A (RAE $\left.\mu \mathrm{g} 100^{-1}\right)$ & $373.9 \pm 26.2$ & 100
\end{tabular}

Values obtained in fresh matter using mean of five replicates; RAE: Retinol Equivalent Activity; nd: not detected.

Table 3. Concentration of the minerals in leaves of E. valerianifolia.

\begin{tabular}{ccc}
\hline Minerals $\left(\mathrm{mg} 100 \mathrm{~g}^{-1}\right)$ & Mean \pm standard deviation & $\%$ \\
\hline $\mathrm{Ca}$ & $79.5 \pm 0.96$ & 11.6 \\
$\mathrm{Mg}$ & $15 \pm 1.83$ & 2.2 \\
$\mathrm{~K}$ & $561.2 \pm 86.46$ & 82.4 \\
$\mathrm{Mn}$ & $1.4 \pm 0.18$ & 0.2 \\
$\mathrm{Zn}$ & $0.4 \pm 0.10$ & 0.05 \\
$\mathrm{Cr}$ & $\mathrm{nd}$ & -- \\
$\mathrm{Na}$ & $1.5 \pm 0.36$ & 0.2 \\
$\mathrm{Se}$ & $0.04 \pm 0.01$ & 0.006 \\
$\mathrm{Fe}$ & $21.6 \pm 0.65$ & 3.2 \\
$\mathrm{Mo}$ & $0.01 \pm 0.01$ & 0.001 \\
$\mathrm{Cu}$ & $0.3 \pm 0.01$ & 0.04
\end{tabular}

Table 4. Potential of nutritional contribution of leaves of E. valerianifolia.

\begin{tabular}{ccc}
\hline \multirow{2}{*}{ Nutrients } & \multicolumn{2}{c}{ E. valerianifolia $(1 \text { portion }=103 \mathrm{~g})^{*}$} \\
\cline { 2 - 3 } Carbohydrates & Concentration/portion & $\%^{* *}$ \\
Proteins & $3 \mathrm{~g}$ & 2.3 \\
Fibers & $1.3 \mathrm{~g}$ & 2.6 \\
Vitamin A & $3.8 \mathrm{~g}$ & 10.1 \\
$\mathrm{Ca}$ & $385.2 \mu \mathrm{gg}$ & 42.8 \\
$\mathrm{Mg}$ & $81.2 \mathrm{mg}$ & 8.2 \\
$\mathrm{~K}$ & $15.4 \mathrm{mg}$ & 3.9 \\
$\mathrm{Mn}$ & $578.1 \mathrm{mg}$ & 12.3 \\
$\mathrm{Zn}$ & $1.5 \mathrm{mg}$ & 63.6 \\
$\mathrm{Cr}$ & $0.4 \mathrm{mg}$ & 3.4 \\
$\mathrm{Na}$ & $\mathrm{nd}$ & -- \\
$\mathrm{Se}$ & $1.5 \mathrm{mg}$ & 0.1 \\
$\mathrm{Fe}$ & $0.04 \mathrm{mg}$ & 75 \\
$\mathrm{Mo}$ & $22.3 \mathrm{mg}$ & 278.2 \\
$\mathrm{Cu}$ & $0.01 \mathrm{mg}$ & 22.7 \\
\hline $\mathrm{Far}$ & $0.3 \mathrm{mg}$ & 29.8 \\
\hline
\end{tabular}

${ }^{*}$ Based on portions of vegetables that provide $30 \mathrm{kcal}$ (Brasil, 2008); ${ }^{* * \%}$ of the contribution calculated according of RDA for people aged 19-30 years old (Institute of Medicine, 2011); nd: not detected. 
However, ionic form of this mineral present in plants $\left(\mathrm{Fe}^{+3}\right)$ has low bioavailability, being influenced by the body Fe reserves and by the amount of potentiating or inhibiting substances that are consumed in the same meal (Scheers et al., 2016).

Samples of E. valerianifolia analyzed in the present study also showed to be excellent sources of $\mathrm{Mo}$ and $\mathrm{Cu}$; good source of $\mathrm{K}$ and source of $\mathrm{Ca}$.

Se is required in very reduced amounts; its concentration in food may change according to its concentration in the soil (Ferreira et al., 2002). The recommendation of daily intake this element for people aged 19 to 30 years is $55 \mu \mathrm{g} /$ day (Institute of Medicine, 2011). However, Donaldson (2004) reports that ingestion in quantities above those of RDA can prevent diseases such as prostrate and cervical cancer.

Leafy vegetables are recognized as good sources of $\mathrm{Mn}$ (World Health Organization, 1998), and E. valerianifolia evaluated in this study presented itself as excellent source of this nutrient.

\section{Conclusions}

E. valerianifolia was considered source of Ca; good source of $\mathrm{K}$ and fibers; and excellent source of pro-vitamin $\mathrm{A}, \mathrm{Mn}, \mathrm{Se}$, $\mathrm{Fe}, \mathrm{Mo}$ and $\mathrm{Cu}$.

The nutritional value demonstrated by this vegetable, associated with its availability in the wild enviroment and its acceptance as a food resource, indicates that this species can supply the daily recommendations of nutrients and contribute to reduce the nutritional deficiency of the population living in regions of occurrence this species. However, more studies should be done on variations in nutrient contents under different environmental conditions in these species.

\section{Acknowledgements}

The authors thank CAPES, CNPq, FAPEMIG and FUNARBE for the granting of scholarships and financial support to carry out this research.

\section{References}

Association of Official Analytical Chemists - AOAC. (2010). Official methods of analysis of the Association of Official Analytical Chemists (17th ed.). Washigton: AOAC.

Barreira, T. F., Paula Filho, G. X., Rodrigues, V. C. C., Andrade, F. M. C., Santos, R. H. S., Priore, S. E., \& Pinheiro-Sant'Ana, H. M. (2015). Diversidade e equitabilidade de Plantas Alimentícias Não Convencionais na zona rural de Viçosa, Minas Gerais, Brasil. Revista Brasileira de Plantas Medicinais, 17(4), 964-974. http://dx.doi. org/10.1590/1983-084X/14_100.

Barrett, D. M., Beaulieu, J. C., \& Shewfelt, R. (2010). Color, flavor, texture, and nutritional quality of fresh-cut fruits and vegetables: desirable levels, instrumental and sensory measurement, and the effects of processing. Critical Reviews in Food Science and Nutrition, 50(5), 369-389. http://dx.doi.org/10.1080/10408391003626322. PMid:20373184.

Brasil. (2008). Guia alimentar para a população brasileira: promovendo a alimentação saudável. Brasília: Ministério da Saúde.
Campos, F. M., Ribeiro, S. M. R., Della-Lucia, C. M., Pinheiro-Sant'Ana, H. M., \& Stringheta, P. C. (2009). Optimization of methodology to analyze ascorbic and dehydroascorbic acid in vegetables. Quimica Nova, 32(1), 87-91. http://dx.doi.org/10.1590/S0100-40422009000100017.

Corbo, M. R., Bevilacqua, A., Campaniello, D., D’Amato, D., Speranza, B., \& Sinigaglia, M. (2009). Prolonging microbial shelf life of foods through the use of natural compounds and non-thermal approaches - a review. International Journal of Food Science \& Technology, 44(2), 223-241. http://dx.doi.org/10.1111/j.1365-2621.2008.01883.x.

Donaldson, M. S. (2004). Nutrition and cancer: a review of the evidence for an anti-cancer diet. Nutrition Journal, 3(19), 19. PMid:15496224.

El-Soda, M., Malosetti, M., Zwaan, B. J., Koornneef, M., \& Aarts, M. G. M. (2014). Genotype $\times$ environment interaction QTL mapping in plants: lessons from Arabidopsis. Trends in Plant Science, 19(6), 390398. http://dx.doi.org/10.1016/j.tplants.2014.01.001. PMid:24491827.

Ferreira, K. S., Gomes, J. C., Bellato, C. R., \& Jordão, C. P. (2002). Concentrações de selênio em alimentos consumidos no Brasil. Revista Panamericana de Salud Pública, 11(3), 172-177. http:// dx.doi.org/10.1590/S1020-49892002000300006. PMid:11998183.

Frary, C. D., \& Johnson, R. K. (2005). Energia. In L. K. Mahan \& S. Escott-Stump (Eds.), Krause: alimentos, nutrição e dietoterapia (Chap. 3, pp. 20-34). São Paulo: Rocca.

Friel, S., Barosh, L. J., \& Lawrence, M. (2014). Towards healthy and sustainable food consumption: an Australian case study. Public Health Nutrition, 17(5), 1156-1166. http://dx.doi.org/10.1017/ S1368980013001523. PMid:23759140.

Gemede, H. H. F., \& Ratta, N. (2014). Antinutritional factors in plant foods: potential health benefits and adverse effects. International Journal of Nutrition and Food Sciences, 3(4), 284-289. http://dx.doi. org/10.11648/j.ijnfs.20140304.18.

Gomes, J. C., \& Oliveira, G. F. (2011). Fotometria de chama e espectrofotometria de absorção atômica. In J. C. Gomes \& G. F. Oliveira (Eds.), Análises físico-químicas de alimentos (Chap. 4, pp. 47-52). Viçosa: Editora da Universidade Federal de Viçosa.

Ignat, I., Volf, I., \& Popa, V. I. (2011). A critical review of methods for characterisation of polyphenolic compounds in fruits and vegetables. Food Chemistry, 126(4), 1821-1835. http://dx.doi.org/10.1016/j. foodchem.2010.12.026. PMid:25213963.

Institute of Medicine - IOM. (2011). Dietary Reference Intakes (DRIs): vitamin a, vitamin $k$, arsenic, boron, cromium, copper, iodine, iron, manganese, molybdenium, nickel, silicon, vanadium and zinc. Washington: IOM.

Paula Filho, G. X., Barreira, T. F., Pinheiro, S. S., Cardoso, L. M., Martino, H. S. D., \& Pinheiro-Sant’Ana, H. M. (2015a). 'Melão croá' (Sicana sphaerica Vell.) and 'maracujina' (Sicana odorifera Naud.): chemical composition, carotenoids, vitamins and minerals in native fruits from the Brazilian Atlantic forest. Fruits, 70(6), 341-349. http:// dx.doi.org/10.1051/fruits/2015035.

Paula Filho, G. X., Barreira, T. F., Rodrigues, V. C. C., Cardoso, L. M., Martino, H. S. D., \& Pinheiro-Sant'Ana, H. M. (2015b). Study of the physical and physicochemical characteristics of fruits of the licuri palm (Syagrus coronata (Mart.) Becc.) found in the Atlantic Forest of Minas Gerais, Brazil. Food Science and Technology (Campinas), 35(3), 474-480. http://dx.doi.org/10.1590/1678-457X.6652.

Pereira, R. A., Duffey, K. J., Sichieri, R., \& Popkin, B. M. (2014). Sources of excessive saturated fat, trans fat and sugar consumption in Brazil: an analysis of the first Brazilian nationwide individual dietary survey. Public Health Nutrition, 17(1), 113-121. http://dx.doi.org/10.1017/ S1368980012004892. PMid:23190560.

Philippi, S. T. (2008). Pirâmide dos alimentos: fundamentos básicos da nutrição (1st ed.). Barueri: Manole. 
Pinheiro-Sant'Ana, H. M., Guinazi, M., Oliveira, D. S., Della-Lúcia, C. M., Reis, B. L., \& Brandão, S. C. C. (2011). Method for simultaneous analysis of eight vitamin $\mathrm{E}$ isomers in various foods by high performance liquid chromatography and fluorescence detection. Journal of Chromatography. A, 1218(47), 8496-8502. http://dx.doi. org/10.1016/j.chroma.2011.09.067. PMid:22014383.

Pinheiro-Sant'Ana, H. M., Stringheta, P. C., Brandão, S. C. C., \& Azeredo, R. M. C. (1998). Carotenoid retention and vitamin A value in carrot (Daucus carota L.) prepared by food service. Food Chemistry, 61(1-2), 145-151. http://dx.doi.org/10.1016/S03088146(97)00084-8.

Rodriguez-Amaya, D. B. (1989). Critical review of provitamin A determination in plant foods. Journal of Micronutrient Analysis, 5(3), 191-225.

Rodriguez-Amaya, D. B., Raymundo, L. C., Lee, T. C., Simpson, K. L., \& Chhichester, C. O. (1976). Carotenoid pigment changes in ripening Momordica charantia fruits. Annales Botanici Fennici, 40(3), 615-624.
Rosas-Romero, A., \& Saavedra, G. (2005). Screening bolivian plants for antioxidant activity. Pharmaceutical Biology, 43(1), 79-86. http:// dx.doi.org/10.1080/13880200590903417.

Scheers, N., Rossander-Hulthen, L., Torsdottir, I., \& Sandberg, A. S. (2016). Increased iron bioavailability from lactic-fermented vegetables is likely an effect of promoting the formation of ferric iron $\left(\mathrm{Fe}^{3+}\right)$. European Journal of Nutrition, 55(1), 373-382. http:// dx.doi.org/10.1007/s00394-015-0857-6. PMid:25672527.

Universidade Estadual de Campinas - UNICAMP. (2011). Tabela brasileira de composição de alimentos: TACO (4. ed.). Campinas: NEPA.

Wahab, N. A., Ahdan, R., Aufa, Z. A., Kong, K. W., Johar, M. H., Mohd, Z. S., \& Ismail, A. (2015). Nutritional values and bioactive componentes of under-utilised vegetables consumed by indigenous people in Malaysia. Journal of the Science of Food and Agriculture, 95(13), 2704-2711. http://dx.doi.org/10.1002/jsfa.7006. PMid:25410129.

World Health Organization - WHO. (1998). Elementos traço na nutrição e saúde humanas. São Paulo: WHO. 